MaPan : Jurnal Matematika dan Pembelajaran

p-ISSN: 2354-6883 ; e-ISSN: 2581-172X

Volume 5, No 2, December 2017 (259-278)

DOI: https://doi.org/10.24252/mapan. v5n2a8

\title{
PENGARUH MOTIVASI BERPRESTASI, MINAT BELAJAR \\ MATEMATIKA, DAN SIKAP BELAJAR MATEMATIKA TERHADAP HASIL BELAJAR MATEMATIKA PADA SISWA SMAN 2 WATAMPONE
}

\author{
Andi Trisnowali MS \\ STKIP Muhammadiyah Bone \\ Kampus: Jalan Abu Dg. Pasolong No. 62 Watampone \\ E-mail: anditrisnowali@gmail.com
}

Submitted: 08-09-2017, Revised: 10-10-2017, Accepted: 10-10-2017

\begin{abstract}
Abstrak:
Penelitian ini merupakan penelitian ex post facto yang bertujuan untuk mengetahui pengaruh motivasi berprestasi, minat belajar matematika, dan sikap belajar matematika terhadap hasil belajar matematika siswa kelas X SMA Negeri 2 Watampone. Populasi dalam penelitian adalah seluruh siswa kelas X SMA Negeri 2 Watampone yang terdaftar pada tahun ajaran 2016/2017. Pengambilan sampel dilakukan dengan cluster random sampling. Pengambilan data dilakukan dengan menggunakan empat instrumen, yaitu kuesioner motivasi berprestasi, minat belajar matematika, sikap belajar matematika dan tes hasil belajar matematika. Data tersebut diperoleh menggunakan bantuan program pengolahan data statistik SPSS versi 20. Hasil analisis statistik deskriptif menunjukkan bahwa hasil belajar matematika siswa kelas X SMA Negeri 2 Watampone dikategorikan tinggi dengan skor rata-rata 76,5 dengan simpangan baku 12,8. Motivasi berprestasi siswa kelas X SMA Negeri 2 Watampone dikategorikan tinggi dengan skor rata-rata 73,3 dengan simpangan baku 9,0. Minat belajar matematika siswa kelas X SMA Negeri 2 Watampone dikategorikan tinggi dengan skor rata-rata 46,2 dengan simpangan baku 4,6. Sikap belajar matematika siswa kelas X SMA Negeri 2 Watampone dikategorikan tinggi dengan skor rata-rata 53,4 dengan simpangan baku 5,7. Hasil analisis inferensial menunjukkan bahwa motivasi berprestasi, minat belajar matematika dan sikap belajar matematika secara bersama-sama berpengaruh secara signifikan terhadap hasil belajar matematika siswa kelas $X$ SMA Negeri 2 Watampone, dengan persamaan regresi $Y=-39,937+0,625 X_{1}+$ $0,737 X_{2}+0,685 X_{3}$. Dengan koefisien determinasi $r^{2}=0,702$. Dari hasil penelitian di atas, maka dapat disimpulkan bahwa terdapat pengaruh motivasi berprestasi, minat belajar matematika dan sikap belajar matematika terhadap hasil belajar matematika siswa kelas X SMA Negeri 2 Watampone.
\end{abstract}

Kata Kunci: Motivasi Berprestasi, Minat Belajar, Sikap Belajar, Hasil Belajar 


\title{
THE INFLUENCE OF MOTIVATION OF ACHIEVEMENT, INTEREST IN LEARNING MATHEMATICS, AND MATHEMATICS LEARNING ATTITUDE TOWARD THE RESULT OF LEARNING MATHEMATICS IN STUDENTS SMAN 2 WATAMPONE
}

\begin{abstract}
:
This research was an ex post facto that aims to determine the influence of achievement motivation, interest in learning mathematics, and the attitude of learning mathematics to the results of learning mathematics class X SMA Negeri 2 Watampone. The population in the study were all students of grade X of SMA Negeri 2 Watampone registered in academic year 2016/2017. Of decide the samples it was applied sampling. The data were collected by using four instruments, namely the achievement motivation koesioner, the interest of learning mathematics, the attitude of learning mathematics and the test of mathematics learning result. Data obtained by using statistical data processing program SPSS 20. The result of descriptive statistic analysis showed that the result of learning mathematics of class X students of SMA Negeri 2 Watampone was categorized high with average score 76,5 with standard deviation 12,8. The motivation of achievement of grade X students of SMA Negeri 2 Watampone is categorized as high with an average score of 73.3 with standard deviation of 9.0. Interest in learning mathematics class X students SMA Negeri 2 Watampone categorized high with an average score of 46.2 with standard simpangan 4.6. Mathematics learning attitude of grade X students of SMA Negeri 2 Watampone is categorized high with average score 53,4 with standard deviation 5,7. The result of inferential analysis shows that achievement motivation, mathematics learning interest and learning attitude of mathematics together significantly influence the learning outcomes of Mathematics of Grade X students of SMA Negeri 2 Watampone, with regression equation $Y=-39,937+0,625 X 1+0,737 X 2+0,685 X 3$. With coefficient of determination $r 2$ $=0,702$. The results of the above research, it can be concluded that there is influence of achievement motivation, interest in learning mathematics and the attitude of learning mathematics on learning outcomes Mathematics class X SMA Negeri 2 Watampone.
\end{abstract}

Keywords: Achievement Motivation, Interest of Learning, Attitude of Learning, Result of Learning

How to Cite: Trisnowali, A. M. S. (2017). Pengaruh Motivasi Berprestasi, Minat Belajar Matematika, dan Sikap Belajar Matematika Terhadap Hasil Belajar Matematika Pada Siswa SMAN 2 Watampone. MaPan : Jurnal Matematika dan Pembelajaran, 5(2), 259-278.

\footnotetext{
$\mathrm{P}$ endidikan yang dibutuhkan oleh bangsa Indonesia adalah pendidikan yang dapat mengembangkan potensi masyarakat, mampu menumbuhkan kemauan, serta membangkitkan semangat generasi bangsa untuk menggali berbagai potensi, dan mengembangkan secara utuh dan menyeluruh (Elfindri dkk, 2012). Matematika adalah salah satu bagian ilmu pengetahuan dasar yang dapat memberikan andil yang sangat besar dalam kemajuan bangsa. Mengingat peranan matematika yang sangat penting itu,
} 
maka siswa dituntut untuk menguasai pelajaran matematika secara tuntas di setiap satuan dan jenjang pendidikan. Namun, pada kenyataannya hasil belajar siswa khususnya mata pelajaran matematika masih relatif rendah. Hal itu dapat dilihat dari nilai rata-rata harian maupun nilai rata-rata ujian siswa, hal ini dibuktikan dari data hasil belajar siswa yang hanya 40\% dari 180 siswa kelas $X$ mencapai nilai standar KKM pelajaran matematika (75) yang ditetapkan disekolah.

Oleh karena itu, dipandang perlu melakukan suatu pengkajian secara sistematis tentang variabel-varibel bersumber dari dalam diri peserta didik, yang secara teoretis memengaruhi hasil belajar matematika. Pengkajian ini dimaksudkan sebagai langkah awal untuk memperoleh informasi yang akurat, agar selanjutnya dapat ditentukan langkah-langkah yang lebih tepat dalam usaha peningkatan hasil belajar matematika dengan membenahi variabelvariabel yang berpengaruh itu.

Sehubungan dengan variabel-variabel yang bersumber dari dalam diri peserta didik yang berpengaruh terhadap hasil belajar matematika, khususnya variabel-variabel yang berbentuk psikis, Begle (1979) menyebutkan antara lain kecemasan, sikap terhadap matematika, motivasi, minat, kepribadian, konsep diri, kecerdasan emosi, berpikir logis, dan sebagainya. Variabel-variabel tersebut ada yang saling berinteraksi yang satu dengan lainnya dan ada yang tidak saling berinteraksi, sehingga diperlukan pengetahuan yang memadai untuk mengetahui variabel yang mana dominan pengaruhnya terhadap hasil belajar matematika.

Mengingat cukup banyak variabel yang bersumber dari dalam diri peserta didik yang berpengaruh terhadap hasil belajar matematika, dan juga keterbatasan peneliti dalam berbagai hal seperti biaya, waktu, dan kemampuan, maka peneliti ini membatasi diri dalam kajiannya, yaitu hanyalah memperhatikan motivasi berprestasi, minat dan sikap belajar peserta didik dalam kaitannya dengan matematika. Dalam kaitanya dengan pemilihan ketiga variabel tersebut, berikut ini dikemukakan pentingnya variabel tersebut.

Goodenought (1945) mengatakan motivasi merupakan variabel yang sangat penting untuk menentukan keberhasilan dalam belajar. Seorang peserta didik atau siswa yang gagal dalam tugas akademiknya disebabkan tidak termotivasi dengan memadai. Begitu pula Nasution (1982) mengatakan bahwa untuk belajar diperlukan motivasi. Semakin tepat motivasi yang diberikan kepada siswa, akan dapat semakin berhasil dalam pelajaran itu. Demikian juga Sardiman (1987) mengatakan bahwa seorang siswa yang memiliki inteligensi 
cukup tinggi, namun mental boleh jadi gagal karena kekurangan motivasi. Hasil belajar akan optimal bila ada motivasi yang tepat.

Kegiatan belajar, minat mempunyai peranan yang sangat penting. Bila seorang siswa tidak memiliki minat dan perhatian yang besar terhadap objek yang dipelajari maka sulit diharapkan siswa tersebut akan tekun dan memperoleh hasil yang baik dari belajarnya. Sebaliknya, apabila belajar dengan minat dan perhatian besar terhadap objek yang dipelajari, maka hasil yang diperoleh lebih baik (Slameto, 2003). Senada yang diungkapkan oleh Nasution (2004), yang menyatakan pelajaran berjalan lancar bila ada minat dan apabila anak-anak malas belajar, mereka akan gagal karena tidak adanya minat. Anakanak yang berminat dalam sebuah aktivitas, berada dimanapun, akan memberikan usaha empat kali lipat untuk belajar dibandingkan anak-anak yang minatnya sedikit atau mudah merasa bosan (Semiawan, 2002).

Sikap merupakan faktor internal psikologis yang sangat berperan dan akan memengaruhi proses belajar (Djaali, 2006). Seseorang akan mau dan tekun dalam belajar atau tidak sangat tergantung pada sikap peserta didik. Dalam hal ini sikap yang akan menunjang belajar seseorang adalah sikap positif (menerima/suka) terhadap bahan/mata pelajaran yang akan dipelajari, terhadap guru, yang mengajar, dan terhadap lingkungan belajar (kondisi kelas, teman-teman, sarana dan prasarana belajar, dan sebagainya). Dalam proses belajar sikap berfungsi sebagai "Dynamic force" maksudnya sebagai kekuatan yang akan menggerakkan seseorang untuk belajar (Palan, 2007). Jadi siswa yang sikapnya negatif (menolak/tidak senang) terhadap materi atau guru tidak akan tergerak untuk belajar, sedangkan siswa yang memiliki sikap positif (menerima/suka) akan digerakkan oleh sikapnya yang positif itu untuk mau belajar.

Ketiga variabel yang dipilih, yaitu motivasi berprestasi, minat belajar matematika, dan sikap belajar matematika sebagai variabel bebas yang akan diselidiki bagaimana pengaruhnya dengan hasil belajar matematika sebagai variabel tak bebas. Hasil yang diperoleh diharapkan dapat menjadi informasi yang berguna dalam upaya meningkatkan hasil belajar matematika pada setiap jenjang pendidikan, khususnya di sekolah menengah atas.

\section{MOTIVASI BERPRESTASI}

Manusia sebagai makhluk hidup mempunyai berbagai macam kebutuhan, baik yang bersifat material maupun yang bersifat psikis. Salah satu kebutuhan psikis adalah kebutuhan untuk berprestasi. Setiap kebutuhan pada 
umumnya menghendaki pemenuhan. Di balik upaya pemenuhan kebutuhan tersebut selalu terdapat motif yang mendorongnya. Motif yang mendorong itu disebut motivasi berprestasi (achievement motivation).

Motivasi berprestasi sebagai suatu kondisi pendorong dalam diri individu yang memegang peranan penting dalam beberapa situasi untuk memelihara atau membuat penampilan atau keunggulan dirinya yang tinggi. Menurut Sardiman (1987), motivasi berprestasi adalah dorongan yang menggerakkan seseorang untuk melakukan keinginan yang dilandasi adanya tujuan mencapai prestasi yang baik. Dengan demikian motivasi berprestasi dapat mendorong usaha-usaha pencapaian hasil belajar yang maksimal termasuk dalam bidang matematika.

Motivasi berprestasi menurut Hilgard (1983) adalah motif sosial untuk mengerjakan seuatu yang berharga atau penting dengan baik dan sempurna untuk memenuhi standar keunggulan dari apa yang dilakukan seseorang. Sedangkan Eysenck dan Wilson (Muhkal, 1994; 50) mengemukakan bahwa orang yang memiliki motivasi berprestasi tinggi mempunyai karakteristik antara lain: berambisi, berkompetensi, bekerja keras, tekun berusaha meningkatkan status sosialnya, dan memberi penilaian yang tinggi terhadap kreativitas dan produktivitas.

\section{MINAT BELAJAR}

Ada beberapa pendapat tentang minat. Menurut pengertian yang paling dasar, minat berarti sibuk, tertarik, atau terlibat sepenuhnya dengan suatu kegiatan karena menyadari pentingnya kegiatan itu. Poerwadarminta (2003) mengemukakan bahwa minat adalah gairah, keinginan dan kecenderungan hati yang tinggi terhadap sesuatu.

Winkel (1983) menyatakan bahwa minat adalah kecenderungan yang agak menetap dalam subyek untuk merasa tertarik pada bidang atau hal tertentu atau merasa senang berkecimpung dalam bidang itu. Perasaan merupakan faktor psikis yang non intelektual, yang khusus berpengaruh terhadap semangat/gairah siswa dalam melakukan aktivitas belajar. Perasaan senang akan menimbulkan minat, yang diperkuat lagi oleh sikap yang positif.

Menurut Crow (1988), minat adalah kemampuan untuk memberi stimuli yang mendorong siswa untuk memperhatikan seseorang, sesuatu barang atau aktivitas, atau sesuatu yang dapat memberi pengaruh terhadap pengalaman yang telah distimuli oleh kegiatan itu sendiri. 
Ahmadi dan Widodo (2004) mengatakan bahwa antara minat dan perhatian pada umumnya dianggap sama atau tidak ada perbedaan. Memang keduanya hampir sama, dan dalam praktek selalu berhubungan satu sama lain. Apa yang menarik minat dapat menyebabkan adanya perhatian terhadap sesuatu tertentu disertai dengan minat.

Minat merupakan momen-momen dari kecenderungan jiwa yang terarah secara intensif kepada suatu objek yang dianggap paling efektif (perasaan, emosional) yang di dalamnya terdapat elemen-elemen efektif (emosi) yang kuat.

Gie (1995) berpendapat bahwa arti penting minat dalam kaitannya dengan pelaksanaan studi adalah sebagai berikut: (1) minat melahirkan perhatian yang serta merta, (2) minat memudahkan terciptanya konsentrasi, (3) minat mencegah gangguan dari luar, (4) minat memperkuat melekatnya bahan pelajaran dalam ingatan, (5) minat memperkecil kebosanan belajar belajar dalam diri sendiri.

\section{SIKAP BELAJAR MATEMATIKA}

Menurut Gerungan (2000) bahwa sikap merupakan suatu kecenderungan untuk mendekat atau menghindar, positif atau negatif terhadap berbagai keadaan sosial, apakah itu institusi, pribadi, situasi, ide, konsep dan sebagainya. Para ahli psikologi telah banyak mendefinisikan sikap dengan berbagai variasi. Namun pada dasarnya pendapat-pendapat tersebut saling melengkapi satu sama lain. Gagne (1987) mengatakan bahwa sikap merupakan suatu keadaan internal (internal state) yang mempengaruhi pilihan tindakan individu terhadap beberapa objek, pribadi, dan peristiwa. Sedangkan menurut Azwar (2005) bahwa sikap adalah evaluasi umum yang dibuat manusia terhadap dirinya sendiri, orang lain, objek atau issue.

Kecenderungan mereaksi atau sikap seseorang terhadap sesuatu hal, orang atau benda dapat diklasifikasikan menjadi sikap menerima (suka), menolak (tidak suka), dan sikap acuh tak acuh (tidak peduli). Nasution (1982) mengklasifikasikan wujud sikap belajar menjadi beberapa klasifikasi, antara lain sebagai berikut: (1) perasaan senang atau tidak senang, (2) perasaan setuju atau tidak setuju, (3) perasaan suka atau tidak suka.

Menurut Azwar (2005) sikap terdiri dari berbagai tingkatan yakni: (1) menerima (receiving), (2) merespon (responding), (3) menghargai (valuing), (4) bertanggung jawab (responsible). 


\section{HASIL BELAJAR MATEMATIKA}

Hasil belajar adalah hasil yang dicapai oleh siswa yang telah mengikuti proses belajar mengajar. Hasil pada dasarnya merupakan sesuatu yang diperoleh dari suatu aktivitas, sedangkan belajar merupakan suatu proses yang mengakibatkan perubahan pada individu, yakni perubahan tingkah laku, baik aspek pengetahuannya, keterampilannya, maupun aspek sikapnya. Misalnya dari tidak tahu menjadi tahu, dari tidak mengerti menjadi mengerti, dari raguragu menjadi yakin, dari tidak sopan menjadi sopan. Jika perubahan tingkah laku adalah tujuan yang ingin dicapai dari aktivitas belajar, maka perubahan tingkah laku itulah yang menjadi salah satu indikator yang dijadikan untuk mengetahui kemajuan individu (siswa) yang telah diperoleh di sekolah.

Menurut Kimble dan Garmezy (Ali, 1987), sifat perubahan perilaku dalam belajar bersifat permanen. Dengan demikian hasil belajar dapat diidentifikasi dari adanya kemampuan melakukan sesuatu secara permanen, dapat diulang-ulang dengan hasil yang sama.

Menurut Abdurrahman (1999), hasil belajar adalah kemampuan yang diperoleh anak melalui kegiatan belajar. Belajar itu sendiri merupakan proses dari seseorang, di mana hasil belajar dipengaruhi oleh inteligensi dan penguasaan anak tentang materi yang akan dipelajarinya.

Adapun rumusan hipotesis penelitian sebagai berikut:

a. Motivasi berprestasi, minat belajar matematika, dan sikap belajar matematika secara bersama-sama berpengaruh terhadap hasil belajar matematika siswa SMAN 2 Watampone.

Untuk keperluan pengujian statistika, hipotesis statistik dirumuskan sebagai berikut:

$\mathrm{H}_{0}: \beta_{i}=0 \mathrm{Vs} \mathrm{H}_{1}: \ni \beta_{i} \neq 0, i=1,2,3$

$\beta_{1}=$ parameter pengaruh motivasi berprestasi

$\beta_{2}=$ parameter pengaruh minat belajar matematika

$\beta_{3}=$ parameter pengaruh sikap belajar matematika

b. Motivasi berprestasi berpengaruh positif terhadap hasil belajar matematika siswa SMAN 2 Watampone.

Untuk keperluan pengujian statistika, hipotesis statistik dirumuskan sebagai berikut:

$\mathrm{H}_{0}: \beta_{1} \leq 0$ Vs $\mathrm{H}_{1}: \beta_{1}>0$

$\beta_{1}=$ parameter pengaruh motivasi berprestasi

c. Minat belajar matematika berpengaruh positif terhadap hasil belajar matematika siswa SMAN 2 Watampone 
Untuk keperluan pengujian statistika, hipotesis statistik dirumuskan sebagai berikut:

$\mathrm{H}_{0}: \beta_{2} \leq 0 \mathrm{Vs} \mathrm{H}_{1}: \beta_{2}>0$

$\beta_{2}=$ parameter pengaruh minat belajar matematika

d. Sikap belajar matematika berpengaruh positif terhadap hasil belajar matematika siswa SMAN 2 Watampone.

Untuk keperluan pengujian statistika, hipotesis statistik dirumuskan sebagai berikut:

$\mathrm{H}_{0}: \beta_{3} \leq 0$ Vs $\mathrm{H}_{1}: \beta_{3}>0$

$\beta_{3}=$ parameter pengaruh sikap belajar matematika

\section{METODE PENELITIAN}

Penelitian yang digunakan adalah jenis penelitian ex post facto atau sering disebut penelitian after the fact. Ex post facto sebagai metode penelitian menunjukkan bahwa perlakuan terhadap variabel bebas telah terjadi sebelumnya, sehingga tidak perlu memberikan perlakuan, tinggal melihat efeknya pada variabel terikat.

Variabel yang diselidiki dalam penelitian ini terbagi dalam dua jenis, yaitu variabel bebas dan variabel terikat. Variabel-variabel bebasnya adalah motivasi berprestasi $\left(\mathrm{X}_{1}\right)$, minat belajar matematika $\left(\mathrm{X}_{2}\right)$, dan sikap belajar matematika $\left(\mathrm{X}_{3}\right)$, sedangkan variabel terikatnya hasil belajar matematika $(\mathrm{Y})$, seperti gambar di bawah ini.

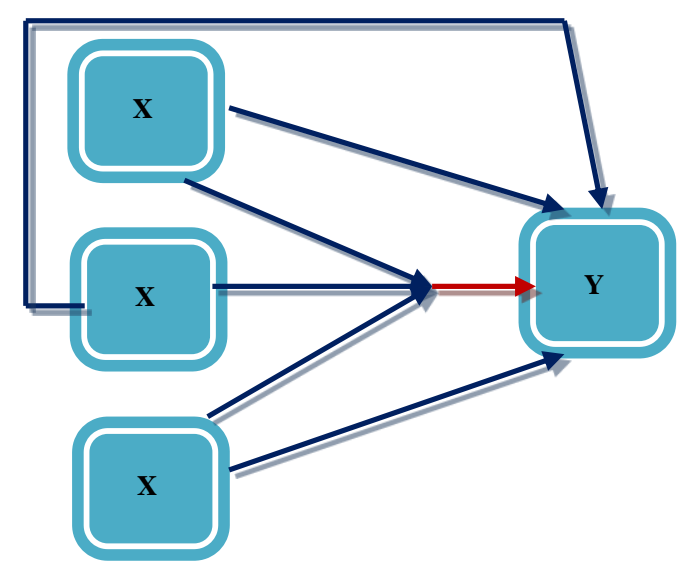

Gambar 1. Skema Desain Penelitian 
Keterangan:

$\mathrm{X}_{1}=$ Motivasi berprestasi.

$\mathrm{X}_{2}=$ Minat belajar matematika .

$\mathrm{X}_{3}=$ Sikap belajar matematika.

$\mathrm{Y}=$ Hasil belajar matematika.

Populasi dalam penelitian ini adalah seluruh siswa kelas X SMAN 2 Watampone tahun pelajaran 2016/2017 yaitu 132 siswa yang tersebar dalam 6 kelas. Metode pengambilan sampel yang digunakan adalah sampel acak berkelompok (cluster random sampling).

Instrumen penelitian yang dipergunakan dalam penelitian ini ada 4 , yaitu: (a) angket motivasi berprestasi, (b) skala penilaian minat belajar matematika, (c) skala penilaian sikap belajar matematika, dan (d) tes hasil belajar matematika siswa. Sebelum digunakan, instrumen-instrumen tersebut terlebih dahulu divalidasi oleh validator yang telah banyak melakukan penelitian yang terkait dengan masalah penelitian matematika.

Angket digunakan untuk mengumpulkan data-data dari variabel bebas yaitu motivasi berprestasi, sedangkan skala penilaian digunakan untuk mengumpulkan data minat belajar matematika dan sikap belajar matematika pada siswa yang menjadi sampel. Angket dan skala penilaian tersebut diisi oleh setiap responden pada waktu dan tempat yang sama. Data-data yang diperoleh dari pengisian angket dan skala penilaian ini merupakan data primer. Sedangkan untuk memperoleh data variabel terikat hasil belajar matematika digunakan tes hasil belajar dengan materi yang telah dipelajari oleh siswa.

Dalam pengolahan data penulis menggunakan teknik-teknik sebagai berikut: (1) editing, yaitu memeriksa kelengkapan dan kejelasan angket/kuisioner yang berhasil dikumpulkan, (2) skoring, yaitu memberikan nilai pada setiap jawaban angket, (3) tabulasi data, yaitu bertujuan untuk menyusun data yang sudah diseleksi dalam bentuk tabel.

Data yang telah diperoleh dianalisis dengan menggunakan teknik analisis statistik, yaitu statistik deskriptif dan statistik inferensial.

a. Analisis Statistika Deskriptif

Statistika deskriptif adalah statistika yang digunakan untuk menganalisis data dengan cara mendeskripsikan atau menggambarkan data yang telah terkumpul sebagaimana adanya, tanpa bermaksud membuat kesimpulan yang berlaku umum. Teknik statistika deskriptif digunakan untuk 
mendeskripsikan karakteristik responden. Untuk keperluan tersebut digunakan tabel distribusi frekuensi, rata-rata, standar deviasi dan persentase.

Jenis data berupa hasil belajar matematika selanjutnya dikategorikan secara kualitatif berdasarkan teknik kategorisasi. Kategori skor untuk hasil belajar matematika dalam penelitian ini menggunakan skala lima

b. Analisis Statistika Inferensial

Analisis statistika inferensial digunakan untuk menguji hipotesis penelitian. Metode analisis yang akan digunakan dalam penelitian ini adalah analisis kuantitatif dengan analisis regresi linear berganda (multiple linear analysis) dan analisis regresi linear sederhana.

Model regresi linear berganda tersebut adalah sebagai berikut:

Adapun model regresi linear sederhana tersebut sebagai berikut:

1. $Y=\beta_{0}+\beta_{1} X_{1}+\beta_{2} X_{2}+\beta_{3} X_{3}+\varepsilon$

Adapun model regresi linear sederhana tersebut sebagai berikut:

1. $Y=\beta_{0}+\beta_{1} X_{1}+\varepsilon$

2. $Y=\beta_{0}+\beta_{2} X_{2}+\varepsilon$

3. $\quad Y=\beta_{0}+\beta_{3} X_{3}+\varepsilon$

Keterangan:

$\mathrm{X}_{1} \quad=$ motivasi berprestasi

$\mathrm{X}_{2}=$ minat belajar matematika

$\mathrm{X}_{3} \quad=$ sikap belajar matematika

$\mathrm{Y} \quad=$ hasil belajar matematika

$\varepsilon \quad=$ random error

$\beta_{1}, \beta_{2}$ dan $\beta_{3}=$ koefisien regresi

\section{HASIL PENELITIAN DAN PEMBAHASAN}

\section{Analisis Statistik Deskriptif}

Hasil analisis statistik deskriptif menunjukkan deskripsi tentang karakteristik distribusi nilai dari masing-masing kelompok penelitian dan sekaligus jawaban atas masalah yang dirumuskan dalam penelitian ini.

a. Hasil Belajar Matematika

Data skor hasil belajar matematika pada siswa SMAN 2 Watampone dapat dilihat pada tabel berikut. 
Tabel 1. Statistik Skor Hasil Belajar Matematika

\begin{tabular}{cc}
\hline Statistik & Nilai Statistik \\
\hline Rata-rata & 76.54 \\
Median & 78.00 \\
Modus & 90.00 \\
Standar deviasi & 12.81 \\
Varians & 164.10 \\
Skewness & -0.46 \\
Kurtosis & -0.39 \\
\hline
\end{tabular}

Dari tabel 1, diketahui bahwa skor rata-rata adalah 76.54 dengan standar deviasi 12.81. Hal ini menunjukkan bahwa tidak terjadinya outlier pada data karena nilai standar deviasi lebih kecil daripada nilai rata-rata. Kesimetrian (kecondongan) dari distrubusi oleh nilai skewness. Skor hasil belajar Matematika mempunyai nilai skewness -0.46 (negatif) yang berarti bahwa kurva distribusi data hasil belajar matematika moncong ke kanan, artinya frekuensi data menunjukkan lebih banyak bernilai tinggi. Keruncingan kurva distribusi ditunjukkan oleh nilai kurtosis. Dari perhitungan yang dilakukan diperoleh nilai kurtosis sebesar 0.39. Dilihat dari nilai kurtosis dapat diketahui bahwa nilai kurtosis $<3$ berarti data termasuk platikurtis (sangat tumpul).

b. Motivasi Berprestasi

Data skor motivasi berprestasi pada siswa SMAN 2 Watampone dapat dilihat pada tabel berikut.

Tabel 2. Statistik Skor Motivasi Berprestasi

\begin{tabular}{cc}
\hline Statistik & Nilai Statistik \\
\hline Rata-rata & 73.36 \\
Median & 75.00 \\
Modus & 75.00 \\
Standar deviasi & 9.05 \\
Varians & 81.99 \\
Skewness & -1.08 \\
Kurtosis & 1.84 \\
\hline
\end{tabular}

Dari tabel 2, diketahui bahwa nilai standar deviasi lebih kecil 9.05 dari pada nilai rata-rata 73.36 yang mengakibatkan tidak terjadinya outlier pada data. Kesimetrian (kecondongan) dari distrubusi nilai skewness sebesar -1.08 yang berarti bahwa kurva distribusi data hasil belajar Matematika menceng ke kanan, artinya frekuensi data menunjukkan lebih banyak bernilai tinggi. 
Keruncingan kurva distribusi ditunjukkan oleh nilai kurtosis. Dari perhitungan diperoleh nilai kurtosis sebesar 1.84 sehingga nilai kurtosis $<3$. berarti data termasuk platikurtis (sangat tumpul).

c. Minat Belajar Matematika

Data skor minat belajar matematika pada siswa SMAN 2 Watampone dapat dilihat pada tabel berikut.

Tabel 3. Statistik Skor Minat Belajar Matematika

\begin{tabular}{cc}
\hline Statistik & Nilai Statistik \\
\hline Rata-rata & 46.19 \\
Median & 46.50 \\
Modus & 41.00 \\
Standar deviasi & 4.64 \\
Varians & 21.57 \\
Skewness & -0.19 \\
Kurtosis & 0.38 \\
\hline
\end{tabular}

Dari tabel 3, skor rata-rata adalah 46.19 dengan standar deviasi 4.64 yang menunjukkan terjadinya outlier karena nilai standar deviasi < nilai rata-rata, sedangkan kesimetrian (kecondongan) dari distrubusi oleh nilai skewness mempunyai nilai skewness -0.19 (negatif) yang berarti bahwa kurva distribusi data condong ke kanan, Keruncingan kurva distribusi ditunjukkan oleh nilai kurtosis. Dari perhitungan yang dilakukan diperoleh nilai kurtosis sebesar 1.96. Dilihat dari nilai kurtosis dapat diketahui bahwa nilai kurtosis $<3$ berarti data termasuk platikurtis (sangat tumpul).

d. Sikap Belajar Matematika

Data skor sikap belajar matematika pada siswa SMAN 2 Watampone dapat dilihat pada tabel berikut.

Tabel 4. Statistik Skor Sikap Belajar Matematika

\begin{tabular}{cc}
\hline Statistik & Nilai Statistik \\
\hline Rata-rata & 53.43 \\
Median & 53.00 \\
Modus & 51.00 \\
Standar deviasi & 5.69 \\
Varians & 32.45 \\
Skewness & -0.15 \\
Kurtosis & -0.40 \\
\hline
\end{tabular}


Dari tabel 4, diketahui bahwa skor rata-rata adalah 53.43 dengan standar deviasi 5.69. Hal ini menunjukkan bahwa tidak terjadinya outlier pada data karena nilai standar deviasi lebih kecil daripada nilai rata-rata. Sikap belajar matematika mempunyai nilai skewness -0.15 (negatif) artinya kurva distribusi data sikap belajar Matematika menceng ke kanan, artinya frekuensi data menunjukkan lebih banyak. Keruncingan kurva distribusi ditunjukkan oleh nilai kurtosis dengan nilai kurtosis sebesar 1.96 sehingga nilai kurtosis $<3$ yang berarti data termasuk platikurtis (sangat tumpul).

\section{Analisis Statistik Inferensial}

a. Pengujian Normalitias

Uji normalitas terhadap residual dari variabel bebas dan variabel terikat dengan uji Kolmogorof-Smirnov menunjukkan nilai signifikansi $0.2(p$ value $>\alpha)$, yang artinya residual berdistribusi normal.

\section{b. Uji Multikolinearitas}

Dari hasil pengujian dengan SPSS diperoleh nilai variansi inflation factor (VIF) ketiga variabel bebas, yaitu Motivasi berprestasi, Minat belajar matematika dan sikap belajar matematika adalah 1.54, 1.94, dan 2.63 lebih kecil dari 5 , sehingga bisa diduga bahwa antar variabel bebas tidak terjadi persoalan multikolinearitas, sehingga dapat disimpulkan bahwa antara variabel bebas tidak terjadi gejala multikolinearitas.

\section{c. Uji Heteroskedastisitas}

Dari hasil pengujian diperoleh nilai $t_{\text {hitung }} X_{1}$ adalah sebesar -.058, $t_{\text {hitung }}$ $\mathrm{X}_{2}$ adalah sebesar -.106 dan $\mathrm{t}_{\text {hitung }} \mathrm{X}_{3}$ adalah sebesar .048 , sedangkan $t_{\text {tabel }}$ adalah sebesar 1.67. Karena thitung $<t_{\text {tabel, }}$ maka dapat disimpulkan bahwa tidak ditemukannya gejala heteroskedastisitas pada model regresi.

\section{d. Pengujian Hipotesis \\ 1. Pengujian hipotesis 1}

Motivasi berprestasi, minat belajar matematika dan sikap belajar matematika secara bersama-sama berpengaruh positif terhadap hasil belajar matematika siswa Kelas X SMA Negeri 2 Watampone. Dalam pengujian statistiknya, hipotesis tersebut dirumuskan sebagai berikut: 
$\mathrm{H}_{0}: \beta_{1}=\beta_{2}=0$ lawan $\mathrm{H}_{1}$ : paling sedikit ada satu $\beta_{1} \neq 0$ atau $\beta_{2} \neq 0$ $\mathrm{H}_{0}$ : Motivasi berprestasi, minat belajar matematika dan Sikap belajar matematika secara bersama - sama tidak berpengaruh positif terhadap hasil belajar matematika siswa kelas X SMA Negeri 2 Watampone.

$\mathrm{H}_{1}$ : Motivasi berprestasi, minat belajar matematika dan sikap belajar matematika secara bersama- sama positif terhadap hasil belajar matematika siswa X SMA Negeri 2 Watampone.

Pedoman yang digunakan untuk menerima atau menolak hipotesis nol $\left(\mathrm{H}_{0}\right)$ yang diusulkan:

a) $\mathrm{H}_{0}$ diterima jika F-hitung $\leq \mathrm{F}$-tabel, atau nilai $p$-value pada kolom sig. $\geq$ level of significant $(\alpha)$

b) $\mathrm{H}_{0}$ ditolak jika F-hitung > F-tabel, atau nilai $p$-value pada kolom sig.< level of significant $(\alpha)$

Dari hasil analisis dengan SPSS menunjukkan p-value $0.00<0.05$, artinya signifikan. Signifikan disini berarti $\mathrm{H}_{0}$ ditolak sehingga $\mathrm{H}_{1}$ yang menyatakan bahwa motivasi berprestasi, minat belajar matematika dan sikap belajar matematika secara bersama- sama positif terhadap hasil belajar matematika siswa kelas X SMA Negeri 2 Watampone.

Persamaan regresi linier $Y$ (hasil belajar matematika) atas $X_{1}, X_{2}$ dan $X_{3}$ (motivasi berprestasi berprestasi, minat belajar matematika dan sikap belajar matematika) yang diperoleh dari perhitungan yang telah dilakukan adalah $Y=$ $-39.937+0.625 X_{1}+0.737 X_{2}+0.685 X_{3}$. Adapun besarnya koefisien determinasi $\left(R^{2}\right)$ adalah 0.702 dengan nilai $r$ adalah 0.838 .

2. Pengujian hipotesis 2

Motivasi berprestasi berpengaruh positif terhadap hasil belajar matematika siswa kelas X SMA Negeri 2 Watampone. Dalam pengujian statistiknya, hipotesis tersebut dirumuskan sebagai berikut:

$\mathrm{H}_{0}: \beta_{1} \leq 0$ lawan $\mathrm{H}_{1}: \beta_{1}>0$

$\mathrm{H}_{0}$ : Motivasi berprestasi tidak berpengaruh positif terhadap hasil belajar matematika siswa kelas kelas X SMA Negeri 2 Watampone

$\mathrm{H}_{1}$ : Motivasi berprestasi berpengaruh positif terhadap hasil belajar matematika siswa kelas X SMA Negeri 2 Watampone

Pedoman yang digunakan untuk menerima atau menolak hipotesis nol $\left(\mathrm{H}_{0}\right)$ yang diusulkan:

a) $\mathrm{H}_{0}$ diterima jika t-hitung $\leq \mathrm{t}$-tabel, atau nilai $p$-value pada kolom sig. $\geq$ level of significant $(\alpha)$ 
b) $\mathrm{H}_{0}$ ditolak jika t-hitung > t-tabel, atau nilai $p$-value pada kolom sig.< level of significant $(\alpha)$

Dari hasil analisis dengan SPSS menunjukkan p-value $0.00<0.05$, artinya signifikan. Signifikan di sini berarti $\mathrm{H}_{0}$ ditolak sehingga $\mathrm{H}_{1}$ yang menyatakan bahwa motivasi berprestasi berpengaruh positif terhadap hasil belajar matematika siswa kelas X SMA Negeri 2 Watampone. Adapun besarnya koefisien determinasi $\left(\mathrm{R}^{2}\right)$ adalah 0.495 dengan nilai $\mathrm{r}$ adalah 0.703 .

3. Pengujian hipotesis 3

Minat belajar matematika berpengaruh positif terhadap hasil belajar matematika siswa kelas X SMA Negeri 2 Watampone. Dalam pengujian statistiknya, hipotesis tersebut dirumuskan sebagai berikut:

$\mathrm{H}_{0}: \beta_{2} \leq 0$ lawan $\mathrm{H}_{1}: \beta_{2}>0$

$\mathrm{H}_{0}$ : Minat belajar matematika tidak berpengaruh positif terhadap hasil belajar Matematika siswa kelas X SMA Negeri 2 Watampone.

$\mathrm{H}_{1}$ : Minat belajar matematika berpengaruh positif terhadap hasil belajar Matematika siswa kelas X SMA Negeri 2 Watampone.

Pedoman yang digunakan untuk menerima atau menolak hipotesis nol $\left(\mathrm{H}_{0}\right)$ yang diusulkan:

a) $\mathrm{H}_{0}$ diterima jika t-hitung $\leq \mathrm{t}$-tabel, atau nilai $p$-value pada kolom sig. $\geq$ level of significant $(\alpha)$

b) $\mathrm{H}_{0}$ ditolak jika t-hitung > t-tabel, atau nilai $p$-value pada kolom sig.< level of significant $(\alpha)$

Dari hasil analisis dengan SPSS menunjukkan p-value $0.036<0.05$, artinya signifikan. Signifikan di sini berarti $\mathrm{H}_{0}$ ditolak sehingga $\mathrm{H}_{1}$ yang menyatakan bahwa minat belajar matematika berpengaruh positif terhadap hasil belajar matematika siswa kelas X SMA Negeri 2 Watampone, Adapun besarnya koefisien determinasi $\left(\mathrm{R}^{2}\right)$ adalah 0.380 dengan nilai $\mathrm{r}$ adalah 0.617 .

4. Pengujian hipotesis 4

Sikap belajar matematika berpengaruh positif terhadap hasil belajar matematika siswa kelas X SMA Negeri 2 Watampone. Dalam pengujian statistiknya, hipotesis tersebut dirumuskan sebagai berikut:

$\mathrm{H}_{0}: \beta_{3} \leq 0$ lawan $\mathrm{H}_{1}: \beta_{3}>0$

$\mathrm{H}_{0}$ : Sikap belajar matematika tidak berpengaruh positif terhadap hasil belajar matematika siswa kelas X SMA Negeri 2 Watampone.

$\mathrm{H}_{1}$ : Sikap belajar matematika berpengaruh positif terhadap hasil belajar matematika siswa kelas X SMA Negeri 2 Watampone. 
Pedoman yang digunakan untuk menerima atau menolak hipotesis nol $\left(\mathrm{H}_{0}\right)$ yang diusulkan:

a) $\mathrm{H}_{0}$ diterima jika t-hitung $\leq \mathrm{t}$-tabel, atau nilai $p$-value pada kolom sig. $\geq$ level of significant $(\alpha)$

b) $\mathrm{H}_{0}$ ditolak jika t-hitung $>\mathrm{t}$-tabel, atau nilai $p$-value pada kolom sig.< level of significant $(\alpha)$

Dari hasil analisis dengan SPSS menunjukkan p-value $0.041<0.05$, artinya signifikan. Signifikan disini berarti $\mathrm{H}_{0}$ ditolak sehingga $\mathrm{H}_{1}$ yang menyatakan bahwa minat belajar matematika berpengaruh positif terhadap hasil belajar matematika siswa kelas X SMA Negeri 2 Watampone. Adapun besarnya koefisien determinasi $\left(\mathrm{R}^{2}\right)$ adalah 0.555 dengan nilai $\mathrm{r}$ adalah 0.745 .

\section{PEMBAHASAN}

Berdasarkan hasil analisis data diketahui bahwa hasil belajar matematika siswa kelas X SMA Negeri 2 Watampone secara umum berada dalam kategori tinggi dengan persentase 50\% dari semua siswa yang menjadi subyek. Hal ini memberikan gambaran bahwa hasil belajar matematika siswa kelas X SMA Negeri 2 Watampone baik tetapi masih perlu ditingkatkan dengan memperhatikan berbagai faktor-faktor lain yang mungkin mempengaruhi hasil belajar siswa.

Selanjutnya, dari hasil analisis data juga diketahui bahwa skor rata-rata motivasi berprestasi sebesar 73.36. Secara umum motivasi berprestasi kelas $X$ SMA Negeri 2 Watampone berada dalam kategori tinggi yaitu besarnya skor angket motivasi berprestasi antara 52.28 dan 81.42 berjumlah 31 siswa (74\%). Motivasi berprestasi merupakan salah satu faktor internal yang penting untuk menunjang pencapaian hasil belajar siswa. motivasi berprestasi yang baik akan memberikan dorongan bagi siswa untuk mencapai hasil belajar yang baik pula. Hal ini berarti dengan tingkat motivasi berprestasi yang tinggi siswa belum dapat memaksimalkan belajarnya untuk mencapai hasil belajar yang baik.

Selanjutnya minat belajar matematika merupakan salah satu hal yang yang ikut menentukan keberhasilan seseorang dalam segala bidang, baik dalam studi, kerja dan kegiatan-kegiatan lainnya. Berdasarkan dari hasil analisis data diketahui bahwa skor rata-rata minat belajar matematika sebesar 46.19. Secara umum minat belajar matematika kelas X SMA Negeri 2 Watampone berada dalam kategori tinggi yaitu besarnya skor angket minat belajar matematika belajar matematika antara 32.83 dan 54.32 berjumlah 29 siswa (69 \%). 
Selanjutnya, dari hasil analisis data juga diketahui bahwa skor rata-rata sikap belajar matematika sebesar 53.43. Secara umum sikap belajar matematika kelas X SMA Negeri 2 Watampone berada dalam kategori tinggi yaitu besarnya skor angket motivasi berprestasi antara 41.95 dan 63.99 berjumlah 18 siswa (43 \%). Sikap belajar matematika merupakan salah satu faktor internal yang penting untuk menunjang pencapaian hasil belajar siswa. Dari masing-masing variabel bebas, ternyata sikap belajar matematika mempunyai konstribusi yang lebih besar jika dibandingkan dengan motivasi berprestasi dan minat belajar matematika (motivasi berprestasi $=49.5 \%$; minat belajar matematika $=38.0 \%$; sikap belajar matematika=55.5\%). Hal ini memberi gambaran bahwa sikap belajar matematika merupakan aspek penting yang perlu dipertimbangkan oleh guru dalam meningkatkan hasil belajar. Sikap belajar matematika sangat diperlukan untuk dapat menyelesaikan berbagai permasalahan matematika sehingga siswa merasa percaya diri dan mampu mengerjakan berbagai soal matematika.

Persamaan regresi linier $Y$ (hasil belajar matematika) atas $X_{1}, X_{2}$ dan $X_{3}$ (motivasi berprestasi, minat belajar matematika dan sikap belajar matematika) yang diperoleh dari perhitungan yang telah dilakukan adalah $Y=-39.937+$ $0.625 X_{1}+0.737 X_{2}+0.685 X_{3}$. Persamaan regresi $Y$ atas $X_{1}, X_{2}$ dan $X_{3}$ tersebut menunjukkan bahwa setiap kenaikan satu unit $X_{1}$ akan mengakibatkan 0.625 unit kenaikan $Y$, kenaikan satu unit $X_{2}$ akan mengakibatkan 0.737 unit kenaikan $Y$, dan kenaikan satu unit $X_{3}$ akan mengakibatkan 0.685 unit kenaikan $Y$. Hal ini menunjukkan bahwa terdapat pengaruh antara $\mathrm{X}_{1}, \mathrm{X}_{2}$ dan $\mathrm{X}_{3}$ dengan $\mathrm{Y}$.

Besarnya koefisien determinasi $\left(\mathrm{R}^{2}\right)$ motivasi berprestasi, minat belajar matematika, dan sikap belajar matematika terhadap hasil belajar matematika adalah 0.702 , hal ini berarti pengaruh atau konstribusi $X_{1}, X_{2}$ dan $X_{3}$ terhadap $Y$ adalah sebesar 70.2\%. Dengan kata lain variasi dalam variabel $Y$ sekitar $70.2 \%$ dapat dijelaskan oleh model persamaan regresi $Y=-39.937+0.625 X_{1}+0.737 X_{2}+$ $0.685 X_{3}$, dengan demikian hipotesis kedua yang menyatakan motivasi berprestasi, minat belajar matematika dan sikap belajar matematika secara bersama- sama berpengaruh positif terhadap hasil belajar matematika siswa kelas X SMA Negeri 2 Kab. Watampone dapat diterima.

Besarnya koefisien determinasi $\left(\mathrm{R}^{2}\right)$ variabel motivasi berprestasi terhadap hasil belajar matematika adalah 0.495 . Hal ini berarti pengaruh atau kontribusi $\mathrm{X}_{1}$ terhadap $\mathrm{Y}$ adalah sebesar $49.5 \%$, dengan nilai $\mathrm{r}$ adalah 0.703 . Dengan demikian hipotesis kedua yang menyatakan motivasi berprestasi 
berpengaruh positif terhadap hasil belajar matematika siswa X SMA Negeri 2 Kab. Watampone dapat diterima.

Besarnya koefisien determinasi $\left(R^{2}\right)$ variable minat belajar matematika terhadap hasil belajar matematika adalah 0.380 . Hal ini berarti pengaruh atau kontribusi $\mathrm{X}_{1}$ terhadap $\mathrm{Y}$ adalah sebesar 38\%, dengan nilai $\mathrm{r}$ adalah 0.617 . Dengan demikian hipotesis kedua yang menyatakan minat berpengaruh positif terhadap hasil belajar matematika siswa X SMA Negeri 2 Kab. Watampone dapat diterima.

Besarnya koefisien determinasi $\left(R^{2}\right)$ variable sikap belajar matematika terhadap hasil belajar matematika adalah 0.555 . Hal ini berarti pengaruh atau kontribusi $\mathrm{X}_{1}$ terhadap $\mathrm{Y}$ adalah sebesar 55.5\%, dengan nilai $\mathrm{r}$ adalah 0.745 . Dengan demikian hipotesis kedua yang menyatakan sikap belajar matematika berpengaruh positif terhadap hasil belajar matematika siswa X SMA Negeri 2 Watampone dapat diterima.

\section{SIMPULAN}

Berdasarkan hasil penelitian dan pembahasan, dapat disimpulkan bahwa hasil belajar matematika, motivasi belajar matematika, minat belajar matematika, dan sikap belajar matematika siswa kelas X SMAN 2 Watampone termasuk dalam kategori tinggi. Kemudian dilihat dari pengarunya bahwa motivasi belajar matematika, minat belajar matematika dan sikap belajar matematika secara bersama-sama mempunyai pengaruh positif terhadap hasil belajar matematika siswa kelas X SMAN 2 Watampone. Sedangkan motivasi belajar matematika, minat belajar matematika, dan sikap belajar matematika mempunyai pengaruh positif terhadap hasil belajar matematika siswa kelas $\mathrm{X}$ SMAN 2 Watampone.

\section{DAFTAR PUSTAKA}

Abdurrahman, M. (1999). Pendidikan bagi anak berkesulitan belajar. Jakarta: Rineka Cipta.

Ahmadi, A. \& Widodo, S. (2004). Psikologi belajar. Jakarta: Rineka Cipta.

Azwar, S. (2005). Sikap manusia teori dan pengukurannya. Yogyakarta: Pustaka Pelajar. 
Begle, E. G. (1979). Critical variables in mathematics educations. Washington D. C: The Mathematical Assosiation of America and The National Council of Teachers for Mathematics.

Crow. (1988). Psikologi pendidikan. Jakarta: Rineka Cipta.

Djaali. (2006). Psikologi pendidikan. Jakarta: Bumi Aksara.

Elfindri, dkk. (2012). Pendidikan karakter. Jakarta: Banduose Media

Gerungan, W. A. (2000). Psikologi sosial. Bandung: Eresco.

Gie, T. L. (1995). Cara belajar yang efisien. Yogyakarta: Liberty.

Goodenought, F. L. (1945). Developmental psychologi an introduction to the study of human behavior (2nd.ed). New York: Applition-Century-Croftes, Inc.

Hilgard, Ernest. (1983). Introduction to psychology. New York: Harcoust B. Javanovic.

Muhkal, M. (1994). Hubungan antara konsep diri matematika dan motivasi berprestasi dengan prestasi belajar matematika Siswa-siswa Kelas 1 SMA Negeri di Kota Madya Ujung Pandang. Thesis. Malang: Institut Keguruan dan Ilmu Pendidikan Malang Program pasca Sarjana.

Nasution. (1982). Berbagai pendekatan dalam proses belajar dan mengajar. Jakarta: Bina aksara.

Nasution. (2004). Didaktik asas-asas mengajar. Jakarta: Bumi Aksara.

Palan, R. (2007). Competency management. Jakarta: PPM Indonesia.

Poerwadarminta, W. J S. (2003). Kamus umum bahasa indonesia. Jakarta: Balai Pustaka.

Sardiman, A. M. (1987). Interaksi dan motivasi belajar mengajar. Jakarta: Rajawali Pers.

Semiawan, C. R. (2002). Belajar dan pembelajaran dalam taraf usia dini. Jakarta: Ikrar Mandiri Abadi. 
Andi Trisnowali MS

Slameto. (2003). Belajar dan faktor-faktor yang mempengaruhinya. Jakarta: Rineka Cipta.

Winkel, W. S. (1983). Psikologi pendidikan dan evaluasi belajar. Jakarta: Gramedia. 